\title{
THE SOUND OF ONE HAND CLAPPING:
}

\author{
A Comment on the "Rank and Filism" Debate*
}

\section{I}

The issue of "spontaneity versus organisation" has provoked constant controversy within labour movements, at least since the polemic between Lenin and Luxemburg in the first years of this century. The rise of mass social-democratic parties and national industrial unions generated a familiar dilemma for the left: an apparent contradiction between direct, localised and immediate collective expressions of working-class experience and aspirations - with the virtues of authenticity and self-activity - and the centralised, co-ordinated and disciplined institutions which strategic efficacy seemingly required. Experience of the particularly bureaucratic and authoritarian German movement helped inspire Michels' eloquent thesis that hierarchical organisational structures were unavoidable, yet inevitably resulted in conservative and anti-democratic outcomes. Others - most notably, perhaps, the Webbs - insisted that oligarchy could be avoided by appropriate organisational engineering; yet others, implicitly endorsing Michels' equation, proposed syndicalist strategies for avoiding institutional discipline. Subsequently the Third International, with its concept of "democratic centralism", sought to dissolve the whole issue by what critics regarded as a definitional sleight-of-hand.

Historiography has, not surprisingly, been deeply affected by these debates. For labour historians, in particular, the identification of the object of enquiry was itself conditioned by attitudes to the question of working-class organisation. How adequately can the study of trade unions and other formal representative institutions encompass the history of labour in its broadest meaning? For the Webbs, proud to regard themselves as bureaucrats, there was no problem. "In spite of all the pleas of modern historians for less history of the actions of governments, and more descriptions of the manners and customs of the governed, it remains true that history, however it may relieve and enliven itself with descriptions of the manners and morals of the people, must, if it is to be history at all, follow the course of continuous organisations." In the main, their successors agreed that the

* I am grateful to the Executive Editor of the International Review of Social History for the invitation to respond to the debate on this topic in the previous issue.

${ }^{1}$ Sidney Webb and Beatrice Webb, A History of Trade Unionism (London, 1894), p. vii. 
priority must be the study of "continuous associations". For half a century or more, what was written as labour history in Britain rarely concerned the humdrum and multifarious experience of everyday workers; the focus was rather the activities of their professional representatives. Labour history was the biography of great organisations. For the most part, even radical historians shared this perspective - even though the organisations and the activities about which they wrote were often distinctive.

Institutionalist labour history eventually faced two challenges: from above and from below. ${ }^{2}$ The historiographical approach pioneered by the Webbs traced organisational developments in almost complete isolation from their broader societal context. The first trade union history to diverge sharply from this tradition was Jefferys' study of the Engineering Union, a work which analysed changes in economic structure, technology and the labour market as conditioning forces upon union evolution. ${ }^{3}$ Hobsbawm was to emphasise the crucial importance of such approaches in the literature produced after 1945: adequate institutional history was obliged to take full account of the economic (and increasingly in the twentieth century, political) context if the trends described were to be rendered meaningful. ${ }^{4}$

The challenge from below consisted of a growing emphasis on the complex texture of everyday life as a determinant of workers' beliefs and expectations (or, more grandly, "culture") and thus of the ground in which formal organisations are rooted. The informal, the ephemeral and the inchoate constitute the essential substratum of associational politics: this insight can be seen in Phelps Brown's sensitive study in 1959 of early twentieth-century industrial relations, ${ }^{5}$ or in Cole and Postgate's pre-war classic, ${ }^{6}$ or even earlier in the work of the Hammonds. In the 1960 s the model of history from below was encouraged not only by the scholarly eloquence of Edward Thompson (and in America, Herbert Gutman) but also by a context of crisis in traditional working-class politics. 1956 (Khruschev's tentative exposure of the crimes of Stalinism, the Polish spring, and the traumatic crushing of the Hungarian uprising) and 1968 (the May événements in France, the wave of student and worker protests across Europe, the resistance to the Vietnam war, and the further discrediting of "actually existing socialism" as the tanks rolled into Prague) symbolised the rupture of inherited definitions of class politics, the labour movement and the socialist project. The theoretical innovations of the New Left, and the practical innovations of shop-floor workers casting aside the etiquettes of

2 I borrow this terminology from Allan Flanders' usage (in a rather different context).

3 James B. Jefferys, The Story of the Engineers (London, 1945).

4 E.J. Hobsbawm, "Trade Union Historiography", Bulletin of the Society for the Study of Labour History, 4 (1964).

${ }^{5}$ E.H. Phelps Brown, The Growth of British Industrial Relations (London, 1959).

${ }^{6}$ G.D.H. Cole and Raymond Postgate, The Common People (London, 1938). 
established collective bargaining machinery, both suggested the precariousness of venerable organisational forms. Many historians participated in these initiatives; others absorbed their influence. One outcome was a symbiosis of labour and social history: arguably enriching dramatically the advance of scholarship in both fields.

It is a commonplace among students of working-class organisation that erstwhile radicals often become a new establishment, to be assailed in their turn by a new insurgent generation. Rarely, however, do the latter nail their standard to the restoration of the ancien régime. Such, however, is seemingly the cause espoused by Jonathan Zeitlin.

" 'Rank and Filism' in British Labour History: a Critique" is itself an historical document. Roughly a third of the text is reproduced word-forword from Zeitlin's 1987 article in the Economic History Review. ${ }^{7}$ It dates back further, however, to the November 1981 conference of the Society for the Study of Labour History, when he and I were plenary speakers. The conference theme was "Industrial Relations c. 1910-1939". In his presentation "Trade Unions and Job Control: a Critique of 'Rank-and-Filism' ", Zeitlin used evidence from his own research into the Engineers before 1914 to challenge an alleged school of historiography inferred from writers (including myself) on contemporary British industrial relations. The years 1910-1939 barely figured in this diatribe ${ }^{8}$ Since that day I have always felt obliged to doubt Zeitlin's historical sensitivity when in his polemical mode.

However it is now somewhat clearer what Zeitlin means by "rank-andfilism". In this journal he indicates four characteristics of the approach. Writers who adhere to this school tend firstly to abandon an institutional focus in favour of "the authentic experience of the ordinary worker, located above all in the workplace and the community". Secondly, they charge official trade unions with a failure to represent "the true interests and everyday concerns of their members". Thirdly, they celebrate challenges to established industrial relations through " 'unofficial' action and 'informal' bargaining". Finally, their research concentrates on periods of exceptional turbulence, most notably the decade 1910-1920 (even though some rankand-filists "have tried to take a longer view").

Zeitlin does not make it altogether clear whether rank-and-filist historians are those who display any, or all, or some combination of these dispositions; but he goes on to suggest that another identifying feature is

7 Jonathan Zeitlin, "From Labour History to the History of Industrial Relations", Economic History Review, XL (1987).

${ }^{8}$ Our respective contributions to the conference were summarised in the Bulletin of the Society for the Study of Labour History, 46 (1983). 
their insistence on a "fundamental division within trade unions" between leaders and rank and file. Some approaches, he states, attribute this division to a differentiation of status and functions within labour organisations (a theme drawn directly or indirectly from Michels); others emphasise the constraints inherent in collective bargaining. "In the more extreme versions of these ideas", he continues, the constraints associated with a mode of unionism primarily oriented towards negotiation are deliberately cultivated by employers. But rank-and-filists also emphasise the precariousness of such constraints: for the institutionalised restrictions of collective bargaining encourage revolts which may "challenge not only the structure of factory authority, but also the stability of the state itself".

According to Zeitlin, implicit in rank-and-filism are "two underlying but highly problematic assumptions". The first is that "trade unions as organisations have an interest in accommodation while their members do not"; the second, that an alternative to accommodation exists: workers possess "a vast reservoir of latent power" which more militant policies could effectively unleash. Several objections are outlined. No clear demarcation can be drawn between "bureaucracy" and "rank and file". To the extent that such a distinction is possible, leaders are often more militant than their members; or at least, are more likely to adopt a solidaristic orientation than members whose concerns are typically sectional and parochial. "Most damaging to the "rank-and-filist' case" is evidence that shop-floor job controls typically depend on formal agreements established by national collective bargaining. Far from undermining workers' influence at the point of production, joint regulation yields more benefits than unilateral controls. Finally, argues Zeitlin, rank-and-filists are mistaken because official trade unions are not remote from the concerns of the membership, but on the contrary are responsive to pressures from below.

Having to his own satisfaction first constructed, and then demolished, the rank-and-filist model of historical analysis, Zeitlin ends by asking how conflict in trade unions may best be understood. While unable to propose a "comprehensive new paradigm" he suggests that an explanation may be found in "two central tensions" within unions. "Externally, trade unions are torn between the demands of opposition and negotiation; internally, between those of centralisation and mobilisation." These contradictory forces do not, however, stem from hierarchical divisions within unions; "the same dilemmas which beset national trade unions reappear within each new form of workers' organisation such as shop stewards' committees or workers' councils". In industrial relations, compromise is inevitable; but the adequacy of any specific compromise is always open to challenge. Instability is thus inherent in the internal politics of unions; yet this in no way derives from "an opposition of objective interest . . . between moderate officials and a militant 'rank and file'". 
In the course of his exposition, Zeitlin identifies seven perpetrators of "rank-and-filist" history: Keith Burgess, James Cronin, James Hinton, Bob Holton, Richard Price, Joseph White, and myself. Two of these authors reply in the same issue of the Review.

Price begins by pointing to an ambiguity of focus in Zeitlin's critique: most of his discussion characterises rank-and-filism as a broad interpretation of trends in industrial relations during the past century, yet his conclusions address the far narrower issue of conflict within unions. Price goes on to deny that the authors castigated can be identified with "the adulation of a militantly pure rank and file"; if they have anything in common it is an interest in the workplace and work control - a focus shared by many other historians (including Zeitlin himself, indeed).

Price emphasises two aspects of his own research. Firstly, he is concerned with the agency of ordinary workers and the contingent dynamics of their relations with employers. Secondly, he locates a constant tension in late nineteenth-century industrial relations in struggles over workplace job control. Thus he insists that "there was a much more ambitious and complex epistemology behind the focus on the workplace, and a more sophisticated scholarly agenda, than Zeitlin either allows or confronts". Zeitlin is charged with oversimplifying his opponents' approaches in a manner which "tends towards caricature". Workplace historians differ from orthodox industrial relations analysts not only in their fondness for radicalism and spontaneity, but also in their conceptual and epistemological frameworks. And while they display considerable variations in their central concerns and analytical emphases, none embraces a simple-minded view of unions as agents of capitalism or of ordinary workers as inherently revolutionary.

Much of Price's article seeks to demonstrate how his own studies of workplace job control, and of the long-term evolution of industrial relations institutions, address complex issues with sophistication. He concedes that there is merit in Zeitlin's conceptualisation of intra-union conflict in terms of factional struggle rather than hierarchical division. Nevertheless, the unequal distribution of internal power cannot be discounted as an influence on the direction and outcome of such struggles: at times, the dynamics of internal union politics indeed match the "rank-and-filist" stereotype. Zeitlin's own counter-examples are drawn from a narrow repertoire of historical instances; he offers no basis for assessing typicality.

The most fundamental objection raised by Price is that Zeitlin neglects "the big question of why British labour developed the way it did". His formulation of a model of internal union conflict is abstracted from any material context. How and why collective bargaining came to be important for trade unions - and hence profoundly influenced their internal development - is not considered. What Zeitlin appears to advocate is a return to traditional historiographical preoccupations with the internal workings of 
industrial relations institutions, divorced from any serious consideration of "the history of gender [. . .], kinship, community, popular culture, workgroups [. . . ]". Thus Zeitlin's approach is "an avowedly conservative one".

For his part, Cronin regards Zeitlin's essay as an expression of the "pessimism and malaise" affecting scholars when labour movements themselves are in disarray or at least on the defensive. Zeitlin's critique is not simply a rejection of "rank-and-filism"; it "amounts to a summary dismissal of the research and writing of almost an entire generation of labour historians [...] a kind of historiographical nihilism". This negativism, Cronin suggests, is sustained by an essentially a priori disregard of the evidence marshalled by those historians criticised.

Cronin, like Price, disputes the "rank-and-filist" label. Zeitlin identifies the "rank-and-filist school" with a belief in the entrenched conservatism of union officials and the militant efficacy of ordinary members. So crudely formulated, such propositions are easy to ridicule; but what historian has ever embraced such oversimplifications? Zeitlin offers no evidence for his diagnosis of these "rank-and-filist assumptions", merely asserts that such beliefs must underlie the approaches with which he disagrees - even though he also concedes that those he criticises do indeed deploy more subtle argumentation. "As critique, therefore, Zeitlin's piece is extremely unsatisfying, largely because it fails to convey what it is that his opponents have done right and wrong."

As for Zeitlin's final suggestions for understanding conflict in trade unions, Cronin finds these so general as to be unobjectionable but unilluminating. Like Price, he asks whether "internal disputes within trade unions" really constitute the fundamental issue of debate. Those castigated as rank and filists have typically embraced wider concerns: "the history of the working class much more broadly conceived". It was precisely this broader focus - and the associated transcending of established institutional boundaries - which characterised the "new labour history" of the 1960 s and 1970s. The generation attacked by Zeitlin was "united less by a common set of assumptions than by a shared historiographic critique" of traditional industrial relations research. This critique led in many directions: towards feminist history; community studies; investigations of ethnic groups; a focus on collective struggles and protests; analyses of the labour process and the experience of work. But unlike Zeitlin, researchers into workplace relations or collective conflict did not regard these as self-contained arenas of study; rather, they saw their work as elements of "the overall project of writing the social history of the working class".

In his rejoinder, Zeitlin states that

Few theoretical paradigms in labour history are so deeply entrenched as "rank and filism" [...]. Three major issues are raised by Price's and 
Cronin's responses to my critique of "rank and filism". What are the theoretical assumptions of "rank-and-filist" historians, and have these been accurately represented in my article? What are the implications for these assumptions of the empirical evidence discussed in my critique? And what is the relationship between "rank and filism" and "workplace history" or the "social history of the working class" more broadly conceived?

The premise of this response, evidently, is to disregard the argument that no "rank-and-filist" paradigm exists. On the contrary, Zeitlin insists that it is perfectly legitimate to have "abstracted and systematised" hypothetical propositions from the varied work of writers none of whom explicitly embrace such positions.

Zeitlin proceeds to recapitulate many of the arguments of the original essay, for the most part engaging only at the margins with the counterarguments of Price and Cronin. At the end of the rejoinder, however, important new themes are developed. Firstly, Zeitlin challenges Cronin's conception of the "social history of the working class".

Between the "lives of ordinary people" or the "actions of ordinary workers" and the "social history of the working class" [. . . stands a significant conceptual gap [. . . ]. The more closely historians have examined the experience of working people, whether in the workplace or the community, the less plausible appears the received image of the working class as a latent collectivity united by objective common interests, and the more salient becomes the role of institutions such as trade unions, political parties and the state in defining the changing contours of collective action and identity.

Secondly, and relatedly, he rejects any interpretation of "workplace history" in terms of "an ongoing power struggle between workers and employers as distinct classes with objectively antagonistic interests". Rather, he insists, "workplace industrial relations in Britain were shaped less by informal social groups or impersonal social and economic processes than by institutional forces: above all the organisation and strategies of trade unions, employers and the state.

In conclusion, Zeitlin denies that the "neo-institutionalist history of industrial relations" which he advocates need "neglect other aspects of workers' lives such as kinship, gender, migration, housing or leisure"; but he insists that "without the theoretical assumption of the working class as a latent collectivity with common interests, there is no reason why such studies should cohere into a unified sub-discipline of 'labour history' [... ]".

III

"Rank-and-filism" has long been a term of abuse directed against radical critics of the policies and functions of trade union leadership: part of a wider 
repertoire of dismissive epithets. For over a century, trade union officials have bemoaned the ingratitude of internal critics, often hinting at devious political motives. ${ }^{9}$ For some fifty years, the Communist Party has castigated "ultra-lefts" who question the role of its favoured union leaders. A synthesis of such dismissive reactions can be found in Geoff Roberts' article "The Strategy of Rank-and-Filism", which preceded by some years Zeitlin's engagement with the theme. ${ }^{10}$

The precise meaning of "rank-and-filism" is not easy to disentangle. As Price and Cronin have already insisted, the seven writers treated by Zeitlin as exemplary cases cannot plausibly be deconstructed as exponents of an underlying "rank-and-filist paradigm". Holton's main work has concentrated on the development of British syndicalism in the early twentieth century and its relationship to the "mass labour revolt" of $1910-1914 .{ }^{11} \mathrm{His}$ main thesis is that syndicalism was through complex mediations an important source of the unrest, and that it remained a vigorous force in 1914. Syndicalist theory, he indicates, criticised "incorporation and bureaucratisation" within unions, but did not regard these as "necessary structural features of trade union development"; and indeed, many syndicalists pursued the consolidation of official union structures. ${ }^{12}$ No attempt is made by Holton to offer a more general theorisation of trade union development or of labour history. White has also adopted a specific focus in his principal published work. His major study covers the same years as Holton, but concentrates exclusively on Lancashire cotton workers. He argues that militancy, while significant, was limited in content and objectives, and stemmed from a complex and specific set of developments in social conditions and work relations. In his conclusion he agrees with the Shorter and Tilly thesis that "organization is somehow the key factor in workers' propensity to strike. In both style and substance, the strikes of the cotton workers would have been inconceivable without generations of union organization and experience. It strongly appears that the best training school for unofficial strikes is official ones." ${ }^{13}$ Scarcely a rank-and-filist declaration! $!^{14}$

\footnotetext{
${ }^{9}$ A couple of illustrations must suffice. In 1875 an Association of Trade Union Officials was reportedly formed to protect full-time officers from "unjust" criticism by dissatisfied members (W. Hamish Fraser, Trade Unions and Society (London, 1974), p. 65); in 1908 George Barnes resigned as secretary of the Engineers, protesting that "there had been the development of an undemocratic feeling in the trade unions which worked out in the direction of mistrust of officials and officialdom" (quoted in Jefferys, Story of the Engineers, p. 168).

${ }^{10}$ Geoff Roberts, "The Strategy of Rank-and-Filism", Marxism Today (December, 1976).

${ }^{11}$ Bob Holton, British Syndicalism 1900-1914 (London, 1976), p. 23.

${ }_{12}$ Holton, British Syndicalism, p. 204.

${ }^{13}$ Joseph L. White, The Limits of Trade Union Militancy (Westport, 1978), p. 180.

${ }^{14}$ See also Joe White, "1910-1914 Reconsidered" in James E. Cronin and Jonathan
} 
All the other authors have sought to develop interpretations of long-run developments in the British labour movement. Two have placed major emphasis on the constraining effects of collective bargaining. Burgess, in his study of industrial relations in four major nineteenth-century industries, argues that many employers favoured collective bargaining because "the cost of any concessions [. . .] was more than compensated by the disciplinary effect which collective bargaining had on the rank and file"; and adds that "isolation of the union official from his members [ . . . ] made him vulnerable to the prevailing ideology of employers [. . . . Instances of 'incorporation' are legion in the late nineteenth century." 15 This "incorporationist" theme is central to his subsequent study of the political representation of labour, culminating in the 1920 s with the Labour Party achieving governmental office. ${ }^{16}$ Yet if in some respects Burgess is evidently a "rank-and-filist" writer, in others he clearly fails to match Zeitlin's model. Far from assuming homogeneous working-class interests, he embraces the "labour aristocracy" thesis and regards the existence of "privileged elites of workers" as a necessary foundation for the emergence of stable collective bargaining. ${ }^{17}$ His writing focuses primarily on the actions and beliefs of leaders and officials, only occasionally descending to the shop floor; while his explanatory model involves largely macrosocial, and in particular economic and technological, factors. And Burgess himself is hesitant in asserting broad generalisations, instead stressing unevenness and historical specificity. ${ }^{18}$

In all these respects the work of Price presents a sharp contrast. In Masters, Unions and Men he identifies the central dynamic of industrial relations as a struggle between employers and workers over the control of the labour process. Here, the efficacy of spontaneous, informal collectivity is stressed; and the growth of encompassing national trade unions with centralised discipline and officials committed to formal collective bargaining procedures is interpreted as an outcome of employers' concerted efforts to reassert their authority over production. ${ }^{19}$ In a series of subsequent papers, Price has sought to generalise some aspects of these arguments;

Schneer (eds), Social Conflict and the Political Order in Modern Britain (London, 1982); in this survey he is concerned to emphasise the very specific sources of militancy in different industries, unions and regions.

is Keith Burgess, The Origins of British Industrial Relations (London, 1975), pp. 308-310.

${ }_{16}$ Burgess, The Challenge of Labour (London, 1980).

${ }^{17}$ Burgess, Origins of British Industrial Relations, p. 309.

${ }^{18}$ See for example Burgess, "New Unionism for Old? The Amalgamated Society of Engineers in Britain" in Wolfgang J. Mommsen and Hans-Gerhard Husung (eds), The Development of Trade Unionism in Great Britain and Germany, 1880-1914 (London, 1985).

19 Richard Price, Masters, Unions and Men (Cambridge, 1980). 
changes in economic structure, technology and work organisation, through the resulting struggles around the labour process, are the essential basis for comprehending trends in labour history; and within the overall experience of labour, the interaction between formal official structures and unofficial rank-and-file activity is a constant feature. ${ }^{20}$ Price's negative assessment of the growth of collective bargaining has evidently helped shape Zeitlin's critique of "rank-and-filism". Nevertheless, as Price himself insists in his response, his arguments are often more nuanced than Zeitlin admits; and certainly there is considerable sensitivity in his subsequent characterisation of labour history as a succession of "negotiations and accommodations", and his insistence on the need to "break free of the stultifying hold of a teleology that, whatever its sophistication, ultimately reduces [. . .] history to a series of universal, absolutist categories of analysis". ${ }^{21}$

Cronin's approach is different again. His research on strikes necessarily entails a focus on the conflictual; and his conclusion that "social and industrial conflict are the means used by ordinary working men and women to assert their changing needs and aspirations" may seem to bespeak a "rank-and-filist" orientation. ${ }^{22}$ Yet there is little evidence of workplace romanticism in Cronin's statistical series and econometric techniques; while much explanatory weight is placed on macroeconomic "long waves". Politics emerge as a central issue in Cronin's more recent work, with his exploration of "the shifting link between working people as a social class and Labour as a political party". ${ }^{23}$ The central conclusion would seem to be the complex and fragile mediations which this linkage involves: political mobilisation is typically detached from everyday social and work experience, while the institutional autonomy of the Labour Party has reinforced the tension between economic militancy and political representation.

Hinton is described by Zeitlin as a Leninist, though how Leninism and rank-and-filism can be compatible is not explained. Certainly his First Shop Stewards' Movement can be regarded as a celebration, albeit critical, of shop-floor organisation and initiative in a decade defined as "a climax of class-conscious self-activity among the workers which, in Britain, has not yet been surpassed". ${ }^{24}$ Drawing on arguments of the shop stewards' movement itself, Hinton argues that the readiness of trade union officials between 1914 and 1918 to co-operate with employers and the government

${ }^{20}$ Price, "Rethinking Labour History: the Importance of Work" in Cronin and Schneer, Social Conflict and the Political Order; "The Labour Process and Labour History", Social History, VII (1983); "The New Unionism and the Labour Process" in Mommsen and Husung, Development of Trade Unionism.

${ }_{21}$ Price, Labour in British Society (London, 1986), p. 12.

22 James E. Cronin, Industrial Conflict in Modern Britain (London, 1979), p. 195.

${ }^{23}$ Cronin, Labour and Society in Britain 1918-1979 (London, 1984), p. vii.

${ }^{24}$ James Hinton, The First Shop Stewards' Movement (London, 1973), p. 13. 
prevented them from articulating effectively their members' grievances. Far from asserting a general theory of incorporation, however, he emphasises the limits to union integration, and stresses the peculiar circumstances of state intervention in wartime production relations. His central concern is to explore the relationship between workplace struggles and broader political projects - the "Soviet idea" - and the contradictory impact of craft traditions on shop steward radicalism. The ultimately (but perhaps not inevitably) divisive and disabling consequences of craft identity help shape the book's conclusions. The view of the "labour movement" as a failed attempt to build universalistic social transformation from a coalition of sectional and defensive interests is in the forefront of Hinton's more recent (and very unLeninist) writing. The "socialist project", Hinton now argues, involves at root "popular control over economic forces"; its relationship to trade union struggle is at best contingent. ${ }^{25}$

What of my own contribution to the "rank-and-filist paradigm"? First it should be said that I am at most a part-time historian; and while my analysis of the present conditions my interpretation of the past (and vice versa), neither can be simply read off from the other. My main historical writing consists, firstly, of a rather conventional institutional history of a trade union. ${ }^{26}$ With James Hinton I have written a brief study of Communist industrial policies in the 1920 s; drawn principally from official sources, this monograph seeks to minimise the significance of the National Minority Movement, seen by many on the left at the time we wrote as the model for a new "Rank and File Movement". ${ }^{27}$ My contribution to the Mommsen and Husung symposium, comparing the periods of industrial turbulence and union expansion in 1888-91 and 1910-14, also emphasises institutional developments, concluding that "two of the most explosive phases of structural transformation in the past century. . . illustrate the remarkable evolutionary adaptability of the machinery of British unionism". ${ }^{28}$ Most recently, my paper on "Rank-and-File Movements" is, as Zeitlin explicitly concedes,

${ }^{25}$ Hinton, Labour and Socialism (London, 1983); "Disconnecting Socialist Aspiration from Class Consciousness", Bulletin of the Society for the Study of Labour History, 51 (1986).

${ }^{26}$ Richard Hyman, The Workers' Union (Oxford, 1971).

${ }^{27}$ Hinton and Hyman, Trade Unions and Revolution (London, 1975).

${ }^{28}$ Hyman, "Mass Organisation and Militancy in Britain: Contrasts and Continuities" in Mommsen and Husung, Development of Trade Unionism, p. 262. In part my argument involves a rejection of Price's interpretation of the pre-war "labour unrest": as Price notes in his response to Zeitlin, the seven supposed representatives of the rank-and-filist school spend a considerable amount of time criticising each other. I have myself published critical reviews of works of Burgess, Cronin and Price in, respectively, International Socialism, 90 (1976); Bulletin of the Society for the Study of Labour History, 40 (1980); and Labour/le Travail, 13 (1984). 
critical of all the main elements which he associates with "rank-and-filist" historiography. ${ }^{29}$

The reader must judge how far these seven authors exemplify a common approach - let alone a "paradigm" 30 - within labour history. Zeitlin insists that "my article self-consciously abstracted and systematized the principles of 'rank and filism' from the work of a variety of writers in which they are present to varying degrees of clarity and explicitness". However, Zeitlin's views on the legitimacy of abstraction and generalisation appear to vary contextually. Diagnoses of a structured conflict between union officials and members, or usage of the concept of class, can be rejected as unacceptable because not fully consistent with empirical evidence; but the "process of abstraction" required to construct the model of "rank-and-filism" can be justified by the need "to assess the empirical validity of a broader theoretical approach rather than an infinite plurality of idiosyncratic individual positions".

It is indeed inevitable if we are to understand the world (or even to express our experiences in language) that we must conceptualise it; and that our conceptualisations, in reducing multiple particularities to a common identity, must oversimplify and distort. Can one however specify acceptable limits to abstraction and generalisation? In part this is a question of levels of analysis - an issue to which I return below. But also relevant is a pragmatic test: how far are the costs in terms of oversimplification outweighed by the gains in analytical purchase?

How well does Zeitlin's notion of rank-and-filism meet this test? In my view, the looseness of his definition of the term vitiates its utility as an instrument in interpreting labour historiography. Two of the elements in his initial characterisation - a focus on detailed social relations rather than formal institutions, and an interest in conflict and turbulence - would encompass virtually every labour historian writing during the past two decades. Is the "critique of rank-and-filism" merely a cloak for a more fundamental rejection of labour history as such, an objective which Zeitlin seemingly embraces?

Only with his two other criteria of rank-and-filism - insistence on a representational gap between union leaders and their members, and enthusiasm for spontaneous and decentralised activism - does Zeitlin's focus become more specific. Yet these themes are also far from the preserve of a coterie of ageing flower-children. A tension between officials and mem-

${ }^{29}$ Hyman, "Rank-and-File Movements and Workplace Organisation, 1914-39" in Chris J. Wrigley (ed.), A History of British Industrial Relations, Vol. 2: 1914-39 (Brighton, 1988).

${ }^{30}$ The Kuhnian notion of paradigm - a set of ontological and epistemological assumptions underlying a protracted phase of "normal science" - is clearly not appropriate as a characterisation of what Zeitlin terms "rank-and-filism". 
bers, as Zeitlin himself notes, was recognised by the Webbs almost a century ago. In the words of a union official writing in 1909, "by slow, almost imperceptible degrees, trade union officialdom has become a profession, and its members a social caste. A distinct interest, growing curiously apart from the general interest of the rank and file, and drifting more and more widely away from democratic sentiment and practice, has evolved." ${ }^{31}$ That the consolidation of giant national trade unions, and the elaboration of formal disputes and bargaining procedures, inevitably compounded such tensions, would once have been considered uncontentious by industrial relations writers of almost any political persuasion..$^{32}$ The corollary which a succession of industrial relations scholars was forced to draw during the 1950s and 1960s was that shop-floor action (particularly in a tight labour market) could yield results which were unattainable through formal collective bargaining. ${ }^{33}$ In the post-war Britain of shop steward organisation and the unofficial strike, all writers on industrial relations were in this sense "rank-and-filists".

In what ways are Zeitlin's target authors more "extreme" than mainstream industrial relations writers? Zeitlin does not address this question. His evident distaste for the "new labour history" perhaps blinds him to the sensitivity to flux and contradiction so evident in most recent historical scholarship. In insisting that a crude and one-sided paradigm must underlie the work of those he attacks, Zeitlin himself falls victim to the Manichean vision which he identifies with "rank-and-filism". The notion of a distinct school of rank-and-filist historians is surely the invention of an unsubtle imagination.

\section{IV}

If the issue of "rank-and-filism" is no more than a confusing diversion, what is the remainder of Zeitlin's message? Four general arguments can be identified. Firstly, collective bargaining yields benefits to union members. Secondly, state intervention assists the achievement of employee rights within the workplace. Thirdly, the positive contribution of formal institutions to the efficacy of job control is amplified by a process of diffusion (organisations "learn" from the experiences of their predecessors). Finally, class analysis is irrelevant to the understanding of industrial relations. ${ }^{34} \mathrm{In}$

${ }^{31}$ Frank Rose of the ASE, quoted in Hinton, First Shop Stewards' Movement, pp. 82-83.

${ }^{32}$ See, for example, the sensitive analysis in Phelps Brown, Growth of British Industrial Relations, pp. 228-235.

${ }^{33}$ A notable instance is the study of industrial conflict in Manchester docks (J. Woodward et al., The Dock Worker, Liverpool, 1955), which identified a mutually conditioning dialectic of official union conservatism and successful rank-and-file militancy.

${ }^{34}$ Zeitlin has developed these arguments in various contexts; for example, "The Emergence of Shop Steward Organisation and Job Control in the British Car Industry", 
addition, as has been seen, Zeitlin proposes that conflict within unions should be understood as the outcome of twin tensions between opposition and negotiation, and centralisation and mobilisation.

None of these propositions is strikingly novel. They complement the rejection of the hypothesised underlying assumptions of "rank-and-filism" - a conflict of interests between union leaders and members, and a massive potential to be won through unfettered rank-and-file militancy. Yet if no serious historian would adopt the crude rank-and-filist stereotype which Zeitlin depicts, it follows that none would totally reject his alternative. If this debate is to yield any constructive outcome, then, we must seek to transcend the stark dichotomies which Zeitlin poses.

The issue of class analysis can receive only cursory treatment in this context. Zeitlin identifies, and rejects, a model of class which can indeed be discovered in the literature: one in which a homogeneous working class confronts an equally homogeneous bourgeoisie, united by common interests which form the basis for increasingly united and class-conscious collective action. But most of those whom he denounces as "rank-and-filists", while insisting on the reality and importance of class struggle ${ }^{35}$ (as, indeed, do most labour historians), would reject any such simplistic formulations. It scarcely requires detailed familiarity with contemporary sociology to appreciate that class analysis can assume many other, often far more subtle forms. Many writers would insist that it makes sense to talk of class structure or class relations without any reference to class interests. Others would argue that class analysis requires no assumptions of internal homogeneitylet alone uniform class consciousness - within classes. Relevant here is the question of levels of analysis: for many Marxists (and some non-Marxists) a stark model of class relations makes sense when interpreting long-term, large-scale social dynamics; but this does not entail a crude characterisation of detailed social relationships at any given historical moment. (In Marx's own writings, the notion of class is used quite differently in the analysis of specific historical conjunctures as against broad generalisations of capitalist evolution). Thus Cronin's project of a "social history of the working class" cannot be sensibly challenged unless it is clear at what level of analysis he is engaged. None of this, of course, is to vindicate class analysis; to do so would require far more complex and detailed argument (and at the end of the day would remain less than conclusive). The point, however, is to

History Workshop Journal, 10 (1980); Shop Floor Bargaining and the State (ed., with Steven Tolliday, Cambridge, 1985); and "Industrial Structure, Employer Strategy and the Diffusion of Job Control" in Mommsen and Husung, Development of Trade Unionism.

${ }^{35}$ Hinton, with his insistence that "socialism is the aspiration of a community, not the destiny of a class" ("Disconnecting Socialist Aspiration", p. 39) is in this respect exceptional. 
establish that a persuasive rejection of class analysis must engage a far more elaborate range of issues than Zeitlin is willing to address. ${ }^{36}$

The other issues raised are somewhat less momentous. Can workers gain from collective bargaining? Can the state assist trade unions in establishing job control? If the questions are posed so starkly, a negative answer is impossible. The interesting problem is: how and why and when are collective bargaining and state regulation advantageous; what costs are associated with the benefits; and how can the balance between the two be influenced $?^{37}$ Because Zeitlin operates at the level of grand polarities, he is either unable or unwilling to pose questions in such terms - understandably, since this would imply that "rank-and-filism" is a matter of degree rather than of absolutes.

The importance of a relativist rather than an absolutist approach to industrial relations is one of the lessons to be drawn from the writings of Gramsci - mentioned by Zeitlin, but not examined at first hand. Every labour historian should mark Gramsci's insistence, in 1920, that "the trade union is not a predetermined phenomenon: it becomes a determinate institution, that is, it assumes a definite historical form, to the extent that the strength and will of the workers who are its members impress a policy and propose an aim that define it" ${ }^{38}$ Historical contingency is thus an essential component of his contribution to the theoretical understanding of trade unionism. Accordingly, Gramsci did not propose a one-dimensional verdict on collective bargaining. On the contrary, he regarded formal negotiations between unions and employers as the expression of an industrial legality - "a great victory for the working class, but. . . not the ultimate and definitive victory". Union officials, as guarantors of this industrial legality, served in periods of industrial stability as defenders of their members' rights. In periods of working-class strength and assertiveness, however, commitment to industrial legality could serve the interests of employers rather than union members ${ }^{39}$ If this is a "rank-and-filist" argument, it is no less plausible on that account!

This leads, finally, to the issue of conflict within trade unions. Zeitlin, as has been seen, attributes this to the twin tensions between opposition and negotiation, and between centralisation and mobilisation; divisions between leaders and members are not part of the explanation. Quoting from

${ }^{36}$ It is worth noting that while "class" is a category at odds with detailed empirical reality, the same is true of the notion of the "state" - a term which Zeitlin employs without embarrassment.

${ }^{37}$ I have attempted to grapple with a number of relevant issues in essays compiled in my recent collection The Political Economy of Industrial Relations (London, 1989).

38 Antonio Gramsci, Selections from Political Writings, 1910-1920 (ed. Quintin Hoare, London, 1977), p. 265.

${ }^{39}$ Gramsci, Political Writings, pp. 285-286. 
the American writer A.J. Muste, Zeitlin insists that opposition to incumbent leaders comes not from "the rank and file, but a rival group of leaders". 40

Here again, the polarity which Zeitlin constructs is unhelpful. If "rankand-filists" are those who interpret all conflict within unions in terms of a clash of interests between leaders and members, then "rank-and-filism" is indeed an absurdity. But it is little less absurd (as Price indicates) to argue that hierarchical divisions are irrelevant to the understanding of intra-union conflict. The tendency for a social and at times ideological divide to develop between full-time officials and their members, as was seen earlier, is so extensively documented as to be regarded as self-evident by virtually every historian of trade unions. Of course it is true that the internal politics of unions often revolve around rival factions within the leadership, or challenges by would-be alternative leaders; but it would require tunnel vision to interpret all internal controversy in these terms. ${ }^{41}$

My own writing on trade unions, certainly, has consistently attempted to explore the interconnections between hierarchical divisions and other sources of conflict. It is in this light that I would approach the "two central tensions" which Zeitlin specifies. Unions, he suggests, are "torn between the demands of opposition and negotiation". In some respects this is an oversimplification: analysts of collective bargaining have often insisted that it is a process which is at one and the same time oppositional and accommodative; in the absence of opposition there would be no need to negotiate. There can be significant variation, however, in the extent to which negotiators focus on "zero-sum" as against "non-zero-sum" issues, and hence in the overtness with which opposition is built into the dynamics of bargaining. It is surely plausible to suggest that professional negotiators are often disposed to concentrate on those issues which are most susceptible to compromise, even when those they represent may have different priorities.

40 A.J. Muste, "Factional Fights in Trade Unions" in J.B.S. Hardman (ed.), American Labor Dynamics in the Light of Post-War Developments (New York, 1928).

${ }^{41}$ Zeitlin is perhaps over-influenced by the arguments of Muste, who wrote in the context of inter-war USA. Partly because of forceful anti-union drives by major employers, the indifference or hostility of state and federal governments towards unions, and perhaps also the lack of cohesion among an ethnically differentiated labour force, grassroots organisation was relatively weak and union structures were strongly hierarchical. Hence intra-union conflict did indeed often take the form of factional rivalry. The development of internal union politics in Britain has been very different: union democracy has reflected many of the structures and traditions of the movement's localised grassroots origins; the number of full-time officials has been relatively small, and their powers more limited than in the US; and anti-leadership traditions (articulated particularly powerfully in The Miners' Next Step) have often proved very influential. It should of course be added that the more recent experience of American unionism (Muste was writing before the creation of the $\mathrm{ClO}$ ) has shown considerable evidence of shopfloor organisation and rank-and-file revolts. 
A very respectable American industrial relations scholar has written that "most students of labor movements would agree [...] that the more a union leader concentrates on collective bargaining, the more conservative he is likely to become. American labor leaders, almost without exception, have moved from left to right as they have gained experience with, and become absorbed by, the process of negotiating and administering treaties with employers." ${ }^{42}$ This is indeed an oversimplification; ${ }^{43}$ but $I$ find it impossible to deny that hierarchical authority and specialisation of functions within unions do overlay the tension which Zeitlin identifies.

The same can be suggested in the case of his tension between centralisation and mobilisation. Again, the dichotomy is not altogether satisfactory; centralised union structures have often been advocated as a more effective means of mobilisation, as the history of mining unionism in Britain clearly demonstrates. What is at issue here, perhaps, is different types of mobilisation: the disciplined, strategically directed campaign as against the spontaneity of guerilla initiatives. In any event, it is important to emphasise that centralisation can have many different meanings and can be pursued for a variety of motives; and again, hierarchical divisions can often overlay these differences. Thus in the decade 1910-20, an important part of the drive towards the formation of large, centralised amalgamations came from shop-floor militants anxious to create a radical fighting organisation. But the actual dynamics of trade union mergers, and the constitutions adopted for the new amalgamated unions, were powerfully shaped by the incumbent leaders; and the result was often to consolidate their own authority over activists at branch and district level. The existing distribution of intra-union power, in other words, conditioned the very meaning of centralisation.

My conclusion should not, I hope, be particularly contentious. Conflict within unions is indeed not "reducible to a cleavage between moderate leaders and a militant 'rank and file' ". But this is not to deny that in certain historical contexts rank-and-file militancy is a reality, and that moderate leaders utilise their position to seek to contain and dissipate insurgency from below. An adequate understanding of the complex dynamics of internal union politics cannot be derived from a crude "anti-rank-andfilism".

\section{V}

Zeitlin is a talented researcher, and labour historians of all persuasions can learn much from his work. In historiography, more than other disciplines

${ }^{42}$ Frederick H. Harbison, "Collective Bargaining and American Capitalism" in Arthur Kornhauser et al. (eds), Industrial Conflict (New York, 1954), p. 277.

${ }^{43}$ As with the very different argument of Muste, it would be rash to assume that Harbison's conclusion can be applied without qualification in the British context. 
perhaps, it is the beginning of wisdom to understand that competing modes of analysis can also prove complementary: our subject surely advances through the constructive engagement of rival schools of thought. Zeitlin's present essay, however, is fatally marred by its negative and destructive character: a one-sidedness which leads merely to sterile point-scoring. What is the sound of one hand clapping? 